\title{
KRIVOPUĆANI I SVI NJIHOVI KARNEVALI
}

\author{
Nevena ŠKRBIĆ ALEMPIJEVIĆ \\ Odsjek za etnologiju i kulturnu antropologiju \\ Filozofski fakultet Sveučilišta u Zagrebu \\ I. Lučića 3, Zagreb \\ Aleksandra VLATKOVIĆ \\ Antuna Šoljana 6 \\ 10000 Zagreb
}

\section{KARNEVALI, ZAJEDNICE, SUPROTNOSTI}

$\mathrm{K}$ rivudajući Krivim Putem u potrazi za pričama o pokladnim zbivanjima u tom kraju, sedamdesetih godina bitno prorijeđenih, poput samog stanovništva koje je sigurniju egzistenciju tražilo u obližnjim urbanim središtima i dalje, uglavnom se može naići na izblijedjele fragmente sjećanja na mačkare zaogrnute kopertama, na Lucu s košarom prepunom jaja i slanine, na rugalice namijenjene onima koji bi se drznuli zatvoriti vrata pred ovim prerušenim posjetiteljima. ${ }^{1}$ Sva su ta kazivanja bila praćena naracijama o životu u selima prepunim mladeži, smijuljenjem vlastitim dogodovštinama iz mladih dana i žâlom za prošlošću, kako pokazuje i opis Luke Krmpotića Brnde iz Veljuna: Sad isto negdar učine te mačkare, ali jako malo. Sad nema nikoga i teže ide. Nekad je bilo naroda pa ovim selima, to bi se mladost okupila. To nije nego za mlada čovjeka. Ja sam išo svake godine, i još jedanput ili dva puta otkad sam se oženio. Tamo šezdesetih sam presta. Ali do nedavno se išlo, dok je bilo dečki i cura po selima. Sad više nema nikoga, samo koji did i baba. Veselje i vrisak je to bilo, sad svud tišina.

Istodobno, kroz tu su krivoputsku tišinu odozdo, s mora, dopirali do nas zvuci vibrirajućeg i vrlo živog, sve brojnijeg i inventivnog, upakiranog u kulturno-turistički proizvod, a ipak saturnalijski iscerenog, Senjskog ljetnog karnevala. Naši su sugovornici krivoputske pokladne likove, koje su većinom ocrtavali kao uniformno uvijene u bjelinu, bez obzira na spol i dob sudionika, nerijetko kontrastirali sa senjskim mačkarama, nastojeći time svoje kazivanje začiniti većom raznolikošću. Tako, primjerice, na pitanje o inverziji spolova na Krivom Putu Mirko Prpić Cungo razgovor spontano skreće prema opisivanju prožetosti senjskoga načina života karnevalskim događanjima: To se u Krivom Putu nisu (prerušavali u suprotan spol, op. a.), nije se to odražavalo dobro jer su to sve bile one iste bijele čipke i to, tako da to nije. U Senju toga ima, ima. Eto moga prijatelja, on se uvijek oblačio u žensku, stalno. Ima male noge, pa je moga nosit ženske cipele. (...) To je u Senju poznato, to svatko sudjeluje. U Senju je bilo poznato dosta da žena bolesna ostane u krevetu, muž ide na bal, ona se poslije obuče, snjim bude, zabavlja ga cilo veře, i dovede ga skoro negdje u ulicu i onda mu reče: "Ajde, idemo kući, biž kući."

No, do kakvih nas dodatnih spoznaja o načinu življenja na Krivom Putu može dovesti analiza pokladnih događanja u lokalitetu koji se, premda prostorno blizak, poziva na drukčije povijesno i kulturno naslijeđe, u gradu u kojem se primorski Bunjevci definiraju kao "ruralni drugi”? (Usp. Škrbić Alempijević 2003:425-444) Tako upisana simbolička razlikovnost Krivopućana u odnosu na Senjane izražava se i u

Višekratna terenska istraživanja vezana uz ovu temu obavile smo na području Krivoga Puta i u gradu Senju u razdoblju od 2003. do 2005. godine, u okviru znanstveno-istraživačkoga projekta "Identitet i etnogeneza primorskih Bunjevaca". Članak koji obrađuje ovu problematiku, u nešto izmijenjenoj varijanti, objavljen je pod naslovom "Krivoputske poklade i senjski karnevali: Uključivanje Krivopućana u ophode s maskama” u Senjskom zborniku 33 (Škrbić Alempijević 2006:377-404). Također su u tekstu korišteni segmenti rada naslovljenog "Godišnji običaji primorskih Bunjevaca", objavljenoga u Senjskom zborniku 32 (Vlatković 2005:317-348). 
pokladnom kontekstu, pri čemu, oslobođena svakidašnjih obrazaca društveno prihvatljivoga ponašanja, poprima smjehovnu dimenziju. Nerijetko se primorskom Bunjevcu u diskursu senjskoga karnevala dodjeljuje identitet lakovjerne žrtve pokladnih vragolija razularene gradske mladeži, pri čemu on podsjeća na Držićeva Stanca izvrgnutog šalama dubrovačkih pokladnih ophodnika te, umjesto pomlađen, završava obrijan i postiđen (Držić 1987:275). Na taj motiv poznat iz hrvatske dramske umjetnosti podsjeća naracija o Peri, čovjeku iz senjske planinske okolice koji nasjeda na predstavljanje Senjanina spolno inverzno prerušenog u "Emiliju": Kao maškara i Milo može postati Emilija... Bilo je već kasno doba kad je Emiliji prilično otežala glava pod maskom $i$ kad su prijatelji počeli značajnim namigivanjem gurati Peru u daljnju fazu avanture s maškarom. Na njihov nagovor dugo joj je šaptao nešto, ona je samo povladivala, a nakon toga ju je Pero onako otežalu s naporom premjestio iz krila na stolicu pokraj sebe i kroz vrevu zateturao prema izlazu. Bura, ona tipična senjska bura, donijela je te karnevalske noći sa sobom i snježnu méáavu. Uostalom, da je vani snijeg i bura, mnogi su u dvorani prvi put primijeti (sic!) po Perinom od vjetra i snijega zgrčenu licu. (Zvrko 1963:23-24)

U pokladnom se kontekstu nesputano progovara i o razlikama u kulturnoj praksi gradskoga stanovništva i njihovih susjeda u zaleđu te o zgodama do kojih dolazi pri dodirima predstavnika tih dviju zajednica, posebice pri doseljavanju Bunjevaca u urbanu sredinu. Tako se, primjerice, u pokladnim novinama Senjskoj metli iz 1939. godine parona Karla i parona Luce s pozicija "starih Senjkinja" parodijski osvrću na gradnju novih bunjevačkih vila u Sv. Martinu. (Uredništvo Senjske metle 1972:28) Mentalna se granica koja odjeljuje ove dvije skupine u senjskim pokladnim napisima podcrtava grotesknim preuveličavanjem i okretanjem karnevaleskne kritičke oštrice prema onim osobinama koje Senjani pripisuju stereotipnoj slici Bunjevca, onoj koju s pozicija moći konstruiraju oni u gospodarskom i administrativnom središtu. Odnos "Senjanin" - "Bunjevac", "urbano" - "ruralno" u vicu je ocrtao Senjanin iz svita postavivši u opoziciju još dva pojma - praščevinu kume Marije i zelje kuma Mile: Imao Mile iz Šojatovog dolca (sic.) u Senju vjenčanu kumu Mariju. Dolazeći u Senj sa tovarima drva i za nabavku živežnih namirnica, svraćao je više puta kumi Mariji, gdje je obično bio pozvan na objed. Da ne bi bilo baš uvijek badava znao je u zimsko doba donijeti kumi Mariji po kilu, dvije zelja. Kuma Marija je skupala (sic.) to zelje i u istoga naravno stavila slanine, kobasic i suhog mesa. Kada bi kum Mile došao na objed i jeo, stalno bi hvalio svoje zelje, te kako je fino, te kako je dobro njegovo zelje. Nikada ne bi spomenuo smok kume Marije, kojega je ova imala, jer je po tadanjim običajima kao svaka kućanica u zimi klala prasce. Kad je ovo kumi Mariji dodijalo, jednoga dana kada je opet kum Mile donio zelje, istoga samo skuha i malo začini a ne dodade svojega smoka. Jede kum Mile za objed ovo zelje, a kako mu se nikako ni dopalo, zapitkivaše kumu Mariju: ma jeli ovo moje zelje, te kako nije kao ono prvašnje. Kuma Marija nato ćemu (sic.): E moj kume tisi (sic.) uvik falil svoje zelje, kako je fino i lipo, a nikada nisi spominjal moje slanine, mesa $i$ kobasic. Eto ti sad tvoje zelje pa ga se nažeri i vidi kako je samo dobro. Kum Mile nije višse od tada donosio zelja, a niti je navraćao kumi Mariji. (Senjanin iz svita 1972:55)

Takvo kontrastiranje identifikacijskih markera predstavlja stalno mjesto i u naracijama o pokladnim običajima Senja i njegove okolice. Senjska karnevalska praksa te ophodi s maskama po obližnjim planinskim selima u dostupnim etnografskim zapisima, a i u kazivanjima naših sugovornika na terenu opisivali su se se kroz čitav niz dihotomija. Najčešće se ukazuje na one polarizacije kroz koje se urbani kulturni inventar odjeljuje od ruralnog. Tako se, primjerice, opisi elaboriranih balova pod maskama, Nobelbala i Pudlbala, te Varošana koji se vrte u ritmovima valcera, mazurke, polke i štajera sučeljavaju s kazivanjima o spontanom hvatanju u kolo na otvorenom, na petunu (betonu) pred crkvom u Podbilu; ; (Bašić 1972:75) nastupi pjevača popularne glazbe i gradske limene glazbe stavljaju se u opoziciju naspram pjesmama seljačkim, ojkanu i ličkim napjevima izvođenim pri ophodima selima na području Krivoga Puta uz zvuke pokoje tamburice, harmonike ili cintare (usne harmonike); (Schneider 2001:21) raskošna su ruha domina, pajaca, vražica, bauta, gospode i gospa, stalnih lica senjskih karnevala te pseudopovijesni kostimi, onaj

\footnotetext{
Jure Tomljanović Ban, Šolići.

Milan Krmpotić Zekonja, Veljun; Eleonora Prpić Lejina, Veljun.
} 
trubadurski blagoglagoljivoga karnevalskog meštra i krinolina njegove kraljice, u pripovijedanju oprečni šutljivim krivoputskim mačkarama umotanim u šlingane plahte, lica prekrivenog miljerima i sa štapovima u rukama, kojima su spremno odbijali znatiželjnike u pokušajima otkrivanja njihova identiteta. ${ }^{4}$ (Schneider 2001:8-9, 19) U naracijama senjskog i krivoputskog stanovništva o pokladnim zbivanjima unutar ove dvije zajednice često se uspostavlja polarizacija koju je hrvatski folklorist Ivan Lozica definirao kao glavnu razliku između gradskih i seoskih karnevala - saturnalijska komponenta, ona kritička i društveno osviještena, kontrastira se s luperkalijskom, magijskom. (Lozica 1997:192-195) Dok se pri opisima gradskih predstavljačkih oblika pozornost često usmjerava na karnevalsku porugu kojom su obuhvaćeni društveni problemi na lokalnoj, nacionalnoj, ali i globalnoj razini (kao što je, primjerice, bio slučaj s pokladnom skupinom koja se 1999. godine svojim alegorijskim vozilom "Biondich-line" parodijski osvrnula na najave o uspostavljanju trajektne linije između Senja i Baške) (Schneider 2001:34), dotle se krivoputski ophodi i dalje nerijetko interpretiraju u svjetlu zazivanja plodnosti i odbijanja zla, kako pokazuje kazivanje Ante Krmpotića Škopca iz Veljuna: A ulazili smo u svaku kuću, zovu te, odi vamo, reče, žito će bolje roditi i sve.

Razgraničavanje sastavnica senjskih i krivoputskih karnevala kroz kategorije živoga i suvremenoga s jedne strane te prošlog i "zastarjelog" s druge djelomice proizlazi iz činjenice da se ti opisi uglavnom odnose na različite vremenske segmente. Pri sakupljanju građe o pokladnim običajima Krivoga Puta pretežito se susrećemo sa sjećanjima na takva događanja koja okvirno sežu od tridesetih do sedamdesetih godina 20. stoljeća, nakon čega su se ophodi mačkara u bjelini održavali samo sporadično, da bi se potkraj toga desetljeća posve dokinuli. Uz to, kazivači redovito upućuju na starinu i kontinuitet krivoputskih pokladnih ophoda, percipirajući ih kao običaj koji su, netaknut ili neznatno izmijenjen, baštinili od onih koji su tu bili prije od nas. ${ }^{5}$ (usp. A. Vlatković 2005:333-338) Višestoljetna se tradicija često stavlja u prvi plan i pri definiranju senjskih karnevala: Stoljećima se u Senju i okolnim mjestima svake subote u mjesecu siječnju i veljači održavaju vesele i temperamentne pučke zabave tzv. balovi tj. maskirane zabave sa plesom pod motom "Mesopust biži ki ča dobije nek i drži”. (Ljubović 2004) No, naracije o senjskim karnevalima u prvom se redu vezuju uz današnje inačice, čiji je parodijski osvrt društveno još uvijek aktualan, koje su najsvježije u kolektivnom pamćenju zajednice te koje su, zahvaljujući brojnosti šarolikih maskiranih povorki iz raznih hrvatskih regija, a i inozemstva, kao i zastupljenosti u medijskom diskursu postale specifičnim kulturnim proizvodom na kojem grad Senj temelji svoj distinktivni identitet.

Nadalje, neke od opozicija uvriježenih u svijesti stanovnika Senja i njegove brdske okolice mogu se protumačiti različitim praksama opisivanja urbanoga te ruralnog kulturnog naslijeđa. Tako zapise o senjskim pokladnim običajima karakterizira neprestano isticanje njihove povijesnosti: već se njihovi rani spomeni u djelu Die Ehre des Hertzogthums Crain Johanna Weicharda Valvasora datiraju u točno određene godine, od 1658. do 1663. (Glavičić 1972:72-73; Valvasor 1689:88; ibid 1970:87) Ispisivanjem senjske pokladne povijesti ispisivala se povijest senjske svakodnevice općenito: mijene koje ova kulturna praksa doživljava prikazivane su u prilozima tiskanim u brojnim gradskim pokladnim novinama (primjerice, Vragoder, Pokladna rašpa, Tovarni list, Ustipci, Labura, Metlica, Metla i škavacera i sl.), koje prate pokladna zbivanja sve od 1875. godine. (Glavičić 1972:3; Ljubović 2004) Konkretna politička i društvena previranja tematizirala su se, oslobođena općeprihvaćenih društvenih restrikcija, upravo u pokladnom kontekstu: tako se izvođenje hrvatskog kola na karnevalskom balu gimnastičkoga društva "Sokol" može shvatiti kao komentar građanstva na poziciju Hrvatske unutar Austro-Ugarske Monarhije. (Uredništvo Narodnih novina 1972:76) Da senjska pokladna zbivanja nedvojbeno predstavljaju dio gradske službene povijesti govori i činjenica da je na Trgu Cilnica 1975. godine Senjsko muzejsko društvo postavilo spomenik u slavu senjskog humora i izlaženja pokladnih (mesopustnih) novina. (Glavičić 1996:356)

$S$ druge strane, pismu etnografa koji su bilježili podatke o tradicijskom načinu življenja na Krivom Putu često je svojstvena ahistoričnost, smještanje priče o "narodnom blagu" u bezvremenski, nerijetko

Ante Krmpotić Škobac, Veljun.

Luka Krmpotić Brnde, Veljun. 
idealizirani okvir. Takav je, primjerice, slučaj s poglavljem "Način života, narodna vjerovanja i običaji” u knjizi Bunjevci Rikarda Pavelića. Kod opisa poklada na nerazmrsiv se način isprepliću podaci koji se odnose na aktualnu kulturnu praksu te one naracije i postupci koje su održavali prvi Bunjevci, kad su došli u ove krajeve 1605. godine. ${ }^{6}$ (Pavelić 1973:183-184) Izostanak jasnijega bilježenja dijakronije tradicijskih pojava primjetan je i u podacima prikupljenim na temelju Upitnice Etnološkog atlasa za lokalitet Krivi Put, pri čemu se o pokladama govori u prezentu: Zovu se mačkare. (...) U djeda se prerušavaju, u cigane, medvjeda. ${ }^{7}$ Pritom je nemoguće ocijeniti je li riječ o pojavama koja su se u trenutku istraživanja još prakticirale ili se tom figurom izriču prošle radnje, svojevrsno "nepromjenjivo" stanje narodne kulture. Ovom je etnografskom diskursu također svojstveno prikazivanje kulture posredstvom kategorije uniformnoga "naroda", koji pasivno s koljena na koljeno prenosi tradiciju prihvaćenu još od "prvih Bunjevaca", za razliku od prikaza senjskih poklada koji su vrlo individualizirani, kako pokazuje i bilješka iz pokladnoga tiska o Senjaninu Juri klesaru, koji je u prvanje vrime... najviše pantomime po gradu delal. (Bašić 1972:75)

Konačno, uzrok postavljanju senjskih i krivoputskih pokladnih običaja u opoziciju je i bitna razlika koju te pojave igraju pri određivanju kulturnoga identiteta njihovih nositelja. Senjski je karneval, posebice onaj ljetni, postao bitnim markerom pri samoidentifikaciji zajednice i njezinu predstavljanju vanjskim promatračima. Spominje se u gotovo svakoj turističkoj brošuri koja ima za cilj promovirati Senj kao grad bogatoga kulturnog naslijeđa i dinamične kulture svakodnevice: Pored Dubrovnika nema kod nas grada, kojega bi prošlost, spomenici i kulturne tradicije bile tako važne za povijest hrvatskoga naroda, kao što je to grad Senj. Senj je grad zanimljiv i važan po svojoj velikoj starini, slavnoj povijesti, starinskim spomenicima, jakoj kulturnoj tradiciji i osobitom životu. (...) Nećete moći zaobići njegovu sadašnjost osobito SENJSKI LJETNI KARNEVAL u kolovozu i morat ćete ostati nekoliko dana da biste se okupali, nauživali svježeg zraka uz obilje sunca, pa tek onda krenuli u obilazak prema najbližim odredištima. ${ }^{8}$ Diferencijacija pokladnih običaja Senja i njegove okolice u sebi uključuje i vrijednosni sud: gradska se karnevalska praksa pritom postavlja kao "etablirana" i "dominantna" u odnosu na onu ruralnu. Takvu su interpretaciju vlastite kulture, proizvedenu u gospodarskom i društvenom središtu regije, uslijed diskontinuiteta održavanja i neprepoznatljivosti njihove prakse u odnosu na maskirane povorke koje ophode širom primorskom regijom, u velikoj mjeri preuzeli i žitelji Krivoga Puta: A mačkare su vam... zapravo prave mačkare su vam bile u Senju. Senjani su imali svoje prave mačkare, oni su se spremali u opremu i tako. Mi smo ovdje na selu imali po seoski, mačkare su bile jednostavne...išla je pretežno omladina, nas desetak, ako ima netko ko zna harmoniku svirat il' usna harmonika. (...) Pazite, Senj ima jednu veliku tradiciju, jedan bal, di vi to ne možete doživjeti, to je bilo nešto zašto je živio grad. (...) To je bila jedna čar, jedna sloboda bila, di ste vi mogli nekoga zafrkavati i tako dalje. Sve vam je tu bilo... sve je bilo. ${ }^{9}$

$6 \quad$ Za detaljniji kritički osvrt na knjigu R. Pavelića, kojim se u prvom redu analizira manjkavost u preciznijem prostornom lociranju podataka (naime, na osnovu iskaza dviju kazivačica autor donosi prikaz triju područja: Krmpota, Krivog Puta i Krasna), usp. Vlatković 2005:319, 338.

7 UEA, IV, 137, Fd 241/1382. Neodređenost razdoblja na koje se podatak odnosi znatno je uvjetovana načinom postavljanja pitanja u Upitnici Etnološkog atlasa - ona su također formulirana u prezentu. Takav vremenska nepreciznost proizlazi iz drukčijega fokusa istraživača u okviru Etnološkoga atlasa Jugoslavije, projekta kojim je šezdesetih i sedamdesetih godina prikupljana građa o elementima tradicijske kulture u približno 3100 lokaliteta diljem tadašnje Jugoslavije i među južnoslavenskim manjinama izvan njezinih granica. Cilj etnološke kartografije, naime, nije pružiti holistički prikaz pojedine teme; ova tehnika svjesno podatak pretvara u grafički simbol koji se upisuje u slijepu etnografsku kartu. "Na taj način etnološke karte služe svom glavnom cilju, da budu... pregledno i pouzdano pomagalo kod rekonstrukcije povijesti tradicionalne kulture i etničkog razvitka nekoga naroda i kod otkrivanja specifičnosti te povijesti." (Bratanić 1959:11-12)

$8 \quad$ www.tz-senj.hr/Hr/Senj_Senj.htm, zadnje pregledano 19. studenoga 2006.

9 Jure Tomljanović Ban, Šolići. 


\section{POKLADNI OBIČAJI KAO SREDSTVO KOHEZIJE ZAJEDNICE}

$\mathrm{N}$ o, senjski i krivoputski pokladni običaji ipak imaju i bitnih dodirnih točaka. One se ne svode isključivo na rekvizite, postupke i tehnike maskiranja svojstvene većini hrvatskih pokladnih inačica, pa time i karnevskom inventaru na senjskom području: u takve se sastavnice, primjerice, ubrajaju posipanje pepelom, podizanje buke, sviranje na raštimanim glazbalima, izvođenje pjesama lascivnoga sadržaja, groteskno prerušavanje pri kojemu u prvi plan dolazi predimenzionirana tjelesnost, inverzija spolova - prerušavanje pojedinaca ili čitave skupine u pripadnike suprotnoga spola itd. Ophodima krivoputskih mačkara te uključivanju u senjske zimske balove i rasplesanu ljetnu povorku zajedničko je i to što ih stanovnici toga kraja u pravilu prikazuju kao događanje oko kojeg se okupljaju svi oni koji se osjećaju pripadnicima dotične zajednice, bilo da su nastanjeni u lokalitetu ili su emigrirali, te koje ima važnu ulogu u samoidentifikaciji njezinih članova. Drugim riječima, pokladne običaje njihovi nositelji poimaju kao sredstvo kohezije zajednice.

Usporedo sa sve većom pozornošću koju mediji, predstavnici raznovrsnih karnevalskih udruga i folklornih festivala u posljednjih desetak godina posvećuju senjskim mesopusnim običajima, posebice Senjskom ljetnom karnevalu, maškare se sve izrazitije kristaliziraju kao prepoznatljivi simbol lokalnoga identiteta među samim stanovnicima Senja. Tako je njihovo sudjelovanje u pokladnim zbivanjima postalo svojevrsnom moralnom obvezom, dokazom naklonosti i povezanosti s mjestom is ostalim mještanima. Osim žitelja danas nastanjenih u gradu, u ophode pod maskama uključuju se i iseljeni Senjani, koji s tom nakanom dolaze iz Rijeke, Zagreba itd. pa time zaključci zimskog i ljetnog karnevala postaju istaknutim danima u lokalnom kalendaru pri kojima se zajednica sastaje, o čemu govore i novinski prikazi karnevalskih ludorija: Senjani tvrde da se pravi vjerni sinovi njihova grada poznaju po tome što i kad napuste Senj pa presele u drugo mjesto, ne propustaju priliku a da ne dođu u Senj, makar samo na jedan februarski bal. Možda u tome malo i pretjeruju, ali činjenica je da su te subote popodne dva autobusa redovne linije stigla do grada pod Nehajem puna putnika a dalje nastavili gotovo prazni. To su došli Senjani koji žive u Rijeci i okolnim mjestima a među njima neki čak iz Zagreba. (Zvrko 1963:23) To je svojstvo senjskog karnevala, iznoseći povijesni pregled nastanka i mijena ove manifestacije, konkretnim individualnim primjerima potkrijepila etnologinja Sanja Schneider: Tako primjerice gda. Karabaić, rodom iz Senja, svake godine dolazi iz inozemstva da bi sudjelovala na Karnevalu pa je postala svojevrsnim simbolom Ljetnog karnevala. 1997. izraden je plakat s njezinim likom za 26. Mecunarodni senjski ljetni karneval. (Schneider 2001:28) No, senjski se karneval poimao kao vrijeme iskazivanja veze emigranata $s$ rodnim krajem i prije negoli su suvremene pokladne inačice postavljene na pijedestal vrijedne kulturne baštine, pa i prije samoga pokretanja ljetnih karnevalskih zbivanja. O tome svjedoče šaljivi napisi objavljivani u pokladnom tisku koje su iseljeni Senjani, u nemogućnosti boravljenja u rodnome mjestu u zimsko karnevalsko doba, upućivali svojim sugrađanima, doprinoseći barem na taj način gradskim pokladnim ludorijama. Takav primjer predstavlja parodijska pjesmica naslovljena "Senjani iz svita - onima u Senj”, koju su članovi Senjske lože iz Zagreba uputili uredništvu pokladnih novina Metla i škavacera 1930. godine:

Poštovani uredniče, dragi,

Lipa fala Vam za lanjske glase;

Metnine nam vo pismo u 'Metlu'

Nek $i$ za nas trun u Senju zna se.

Rado mi bi danas doli došli,

Da nam bude tamo lipšse svima.

Ma ča ćete, kad vam zeleznice

Jos do doli, do dandanas nima! (...)

Sad imamo ovdi 'Senjsku ložu',

Ne za šulac i za bedastoće,

Pa uz litru sitimo se uvik 
Na sve Vaše fufinje i floće. (...)

Mi ćemo se od sad za Vas starat

Golubi će padat Van u usta,

Strpite se samo lipo, mirno

Do drugoga jopet-Mesopusta.

(Senjska loža u Zagrebu 1972:14)

Sličnu su funkciju u razdoblju njihova intenzivnog održavanja, do prije četrdesetak godina, na razini krivoputske zajednice igrali zimski pokladni ophodi skupina prerušenih u bjelinu. (Vlatković 2005:337) Tako je pri ophodima selima Krivoga Puta nepisano pravilo bilo da se višednevnim ophodom obuhvate sva domaćinstva na tom području, izuzev onih koje je nedavno pogodila smrt ili teška bolest ukućanina. ${ }^{10}$ (Vlatković 2005:335) Stanovnici Krivoga Puta određivali su se kao pripadnici svoje zajednice sudjelujući na različite načine u pokladnim događanjima, bilo kao članovi prerušene skupine, bilo kao sudionici u pripremama i pripravljanju gozbe, bilo kao domaćini koji su bili dužni pogostiti mačkare. Tako su oni koji bi odbili gostoprimstvo prerušenim ophodnicima, osim nepodopštinama maskiranih ophodnika, simbolički bili kažnjavani i od strane čitave zajednice, naracijama koje su o njima prenosile nakon završetka pokladnoga razdoblja te njihovim umanjenim ugledom u očima suseljana.

Jedan od načina iscrtavanja simboličkih granica zajednice predstavljao je i odabir prostora obuhvaćenog pokladnim ophodom: sva ta naša sela krivoputska obidi obavezno, i to je tako grupa iz svakog našeg zaselka išla i činila, a onda drugdi ako pristignu. ${ }^{11} \mathrm{~S}$ krivoputskog su se područja maskirane skupine nerijetko upućivale i u druge lokalitete nastanjene primorskim Bunjevcima: u Vratnik, u Senjsku Dragu, u Melnice itd. O činjenici da sama blizina nije bila jedini ili barem ne presudni čimbenik pri određivanju prostora ophoda svjedoče kazivanja o rjeđem upućivanju u obližnja pravoslavna sela Prokike i Ritavac te o fizičkim sukobima do kojih bi povremeno pritom dolazilo između mačkara i mještana, njihovih etničkih i vjerskih "drugih".

Važnost ophoda s maskama pri iskazivanju pripadnosti krivoputskoj zajednici, odnosno samoidentifikaciji njezinih pripadnika, iščitava se i iz podataka o boravku iseljenih Krivopućana u rodnim selima upravo tijekom vikenda u pokladnom razdoblju, kako bi aktivnim sudjelovanjem u tim običajima pokazali da nisu zaboravili odakle su: Jer to se radilo okolo. Po Slavoniji smo delali, otac moj, ja nisam, ja sam ovdje po Rijeci. I cure su išle, dolje u Senju je bila tvornica "Neda" pa su radile. Onda dodu obavezno priko tih pokladnih vikenda ovdje. Onda su išle, kako veli, u mačkare. ${ }^{12}$

Međutim, uslijed intenzivne depopulacije Krivoga Puta u posljednjih četrdeset godina pokladni su se ophodi mačkara u bjelini održavali sve rjeđe, dok se danas mogu zabilježiti samo kroz naracije starijeg stanovništva još uvijek naseljenog na tom području. Do nove egzistencije krivoputske pokladne prakse dolazi nedavnom inicijativom učiteljice iz lokalne škole, pri čemu je ulogu maskiranih ophodnika danas preuzela šačica djece u okviru svojih izvanškolskih aktivnosti: Sad mi dicu tu mačkaramo, učiteljica ode sa dicom, onda dica dođu, a narod prizadovoljan, onda daje dici novce, jaja, svašta, ajd. Kaže "To je sretna godina, došle mačkare u kuću". ${ }^{13}$

Ipak, takvi ophodi više ne služe kao sredstvo kohezije odraslih žitelja Krivoga Puta niti potiču iseljeno stanovništvo na privremeni boravak u rodnom kraju u cilju uključenja u te običaje. Stoga u promijenjenim okolnostima i u drugim sredinama bunjevačko stanovništvo s Krivoga Puta nalazi nove načine uključivanja u ophode s maskama. Pritom distinktivne sastavnice nekadašnjih krivoputskih ophoda pod maskama prenose i uklapaju u ophode u mjestima sadašnjeg obitavanja, posebice u slučajevima kad su u

UEA, IV, 137, Fd 241/1382; Ivan Krmpotić Šoparin, Šojatski Dolac, zaselak Škopci.

11 Luka Krmpotić Brnde, Veljun.

2 Ivan Krmpotić Bokulić, Veljun.

3 Mara Tomljanović, Krivi Put. 
određenom lokalitetu koncentrirani u većem broju u pojedinim gradskim četvrtima. Takav primjer predstavljaju dječji ophodi u Senju: unuka Krivopućanina Mirka Prpića Cunge, koja od rođenja živi u Senju, pri pokladnom obilasku susjednih kućanstava nerijetko preuzima ulogu Luce, zadužene za prikupljanje darova i nošenje košare pune poklonjenih delicija od kuće do kuće. ${ }^{14}$ (Vlatković 2005:338) Taj lik, kojeg su na Krivom Putu mogli utjelovljivati pripadnici obaju spolova, ranije nije bio zastupljen u senjskom pokladnom inventaru, a o Lucinim zadaćama i načinu ophođenja djevojčica i njezini vršnjaci doznali su iz pripovijedanja Mirka Prpića. Na taj način i pokladni običaji nove sredine, osim što služe kao način interakcije doseljenih sa zatečenim stanovništvom, također otvaraju prostor za iskazivanje još žive veze $s$ krivoputskom zajednicom, neumanjene fizičkom odsutnošću njezinih članova.

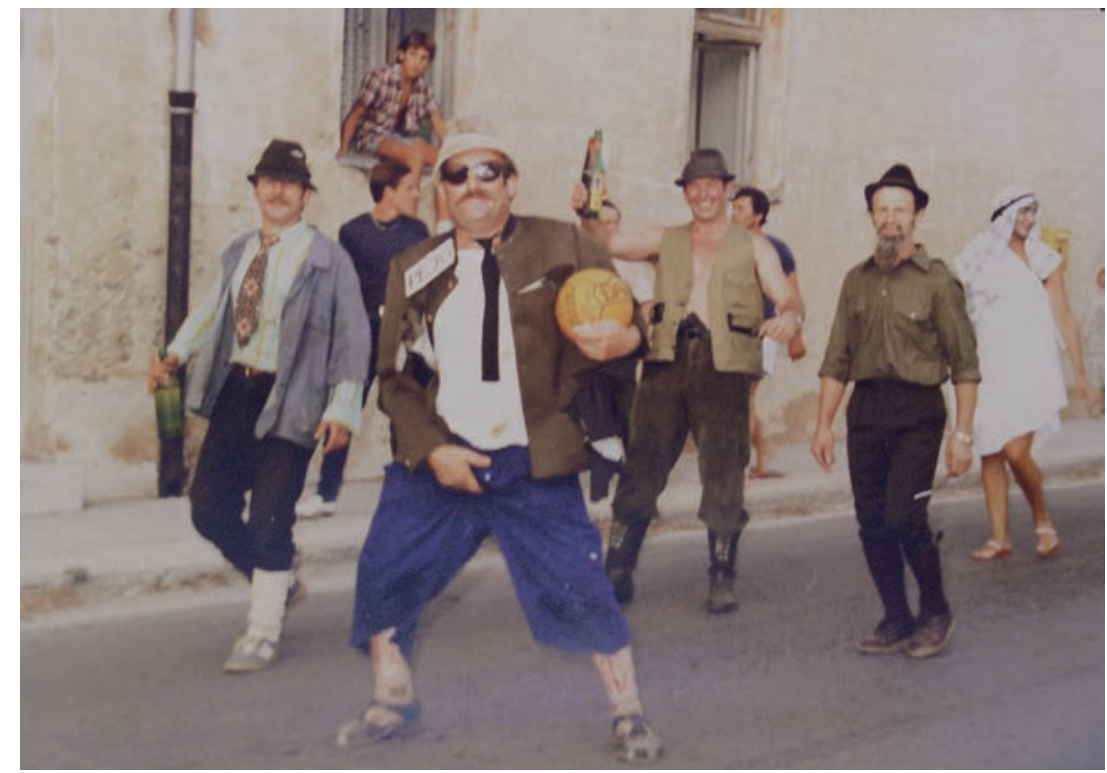

Slika 1: Ophod alanarskih mačkara senjskim ulicama sedamdesetih godina 20. stoljeća; ir foto-albuma Vladimira Biondića Dujanova iz, Alana.

No, usporedo sa sve rjeđim održavanjem ophoda s maskama u planinskoj okolici, senjski karnevali postaju središtem oko kojeg se u sve većoj mjeri okuplja i stanovništvo još uvijek nastanjeno u gradskom zaleđu (sl. 1). Stoga su u daljnjem tekstu, ukazujući na glavne sastavnice ophoda s maskama, s posebnim osvrtom na načine uključivanja Krivopućana u njih, ravnopravno prikazani pokladni običaji krivoputskoga područja od tridesetih do sedamdesetih godina 20. stoljeća te senjska karnevalska zbivanja, kako ona o kojima piše još Valvasor, tako i suvremena, kao noviji prostor za ostvarivanje primorsko-bunjevačke običajne prakse. U poglavljima koja slijede iznesen je prikaz ovih triju pokladnih inačica, krivoputskih ophoda, senjskih zimskih te ljetnih karnevala.

\section{KRIVOPUTSKI POKLADNI OPHODI}

$\mathrm{P}$ okladna preobrazba podrazumijevala je usvajanje drukčijih normi ponašanja, bitno različitog, nerijetko i devijantnoga moralnog koda: Ne mo's se ti sa mačkarama pravdat, sa mačkarama nema suda. Mo’s ga ubit maskiran. Ne može ti ni policija ni niš. Niko ništa. ${ }^{15} \mathrm{Za}$ takvim je fiktivnim identitetom tijekom vikenda u pokladnom razdoblju, a naročito intenzivno zadnje subote pred Pepelnicu, posezala grupica mladeži iz svakog zaselka na Krivome Putu. ${ }^{16} \mathrm{U}$ ophod su se, otkada seže sjećanje kazivača, uključivali

14 Mirko Prpić Cungo, Senj.

15 Ante Krmpotić Škobac, Veljun.

16 UEA, IV, 137, Fd 241/1382. 
pripadnici obaju spolova koji još nisu stupili u brak, rjeđe netom oženjeni muškarci, a mlađe udate žene samo sporadično. Ovakvi su obilasci selima do konca sedamdesetih godina, dakle u čitavu razdoblju njihova intenzivna održavanja, bili namijenjeni samo odraslima. Tek posljednjih godina, četrdesetak godina nakon što su mačkare u bjelini prestale obilaziti Krivim Putem, ovim su krajem krenule povorke sačinjene od učenika krivoputske osnovne škole.

Mačkare su selima Krivoga puta obilazile najčešće subotom, te rjeđe nedjeljom. Družinu bijelih mačkara obično je činilo petero do desetero mačkara, dok se iz većih sela, poput Veljuna, upućivala i skupina od dvadesetero ophodnika. Članovi maskiranih skupina pretežito su bili uniformno odjeveni, bez obzira na njihovu rodnu pripadnost; istovjetni se karnevalski odjevni kod odnosio i na svirače koji su se uključivali u ophod. ${ }^{17}$ Oprema, dostatna da se zbaci svakidašnji identitet Krivopućana i privremeno usvoji onaj mačkarski, transgresivni i liminalni, najčešće je bila načinjena od koperti $^{18}$, kuvarica $^{19}$ i plahti, vrlo često štikanih ${ }^{20}$, miljera ili ručnika. Ponakad su sudionici oblačili i široke šlingane haljine, a preko njih košulje ${ }^{21}$ ili bijele kiklje $^{22}$. Na glavu su stavljali šešire ili šubare, a lice su zakrivali rupcima ili miljeima, kukičanim tabletićima. Dodatno su se kitili raznobojnim krep-papirom izrezanim u dugačke trake, široke otprilike tri centimetra, koje bi pričvrstili odostraga na odjeću. Sami su izrađivali maske od kartona, dok su od sredine dvadesetog stoljeća najčešće u Senju kupovali plastične maske. Sve mačkare u povorci nosile su štapove, radi obrane od pasa te mogućih fizičkih obračuna s ponekim nenaklonjenim mještaninom. Često je u pokladnom razdoblju dolazilo do obostrane običajne inverzije spolova. Pritom su se muškarci zaogrtali plahtama, koje su oblikovali poput suknje, od krpa su oblikovali fiktivne ženske obline, a preko njih bi navlačili bušt ${ }^{23}$ Ophodnici s brkovima domaćinima čije su kuće obilazili ponekad su se predstavljali kao "brkate cure". No, češće do takvih suprotnih rodnih signala nije dolazilo, budući da su mačkare u većini slučajeva lice prekrivali miljeom ili kakvom mrežastom tkaninom. Prilikom prerušavanja u žensku odjeću muškarce su obično savjetovale žene, članice obitelji ili odabranice; pomagale su im u prikupljanju rekvizita i u spremanju. Kostimografska preobrazba nije bio jedini signal predstavljačkog prijelaza s onu stranu rodne granice: spolno inverzno preobučeni muškarci također su oponašali ženski glas. Djevojke su svoj običajni muški identitet u prvom redu naznačavale muškom odjećom: oblačile su hlače, a na glavu stavljale šešir. Premda im se lice nije vidjelo u većini su slučajeva od ovčje kože i vune također oblikovale brkove.

Unutar skupine uglavnom se isticala Luca. Taj je lik, poput drugih mačkara, bio prerušen u bijelu plahtu, sa šubarom ili kapom na glavi. Ipak, njezina je preobrazba bila razlikovna, budući da je nosila košaru u koju su domaćini odlagali darove za ophodnike: jaja, kobasice, sir, slaninu, rjeđe vino, rakiju i novce. Luca je usvajala i nešto drukčiji način ponašanja: za razliku od ostalih sudionika, taj lik nije plesao u kućanstvima niti se upuštao u lascivne šale s neudanim članicama obitelji, već je domaćinima najavljivao zaključak boravka mačkara u njihovu domu neizostavnim: Dajte Luci što vam je pri ruci. ${ }^{24} \mathrm{Za}$ tu se ulogu uglavnom odabirala osoba (muškarac ili žena) jače fizičke konstitucije, kako bi lakše mogla ponijeti svoj teret, te koja nema sklonosti plesu. ${ }^{25}$ No, u slučajevima kad su ostali sudionici bili voljni Luci pomoći nositi košaru, ovaj lik je mogla utjeloviti i slabija osoba, pa i dijete. ${ }^{26}$

Svirači su najčešće su svirali harmoniku, usnu harmoniku - cintaru ili tamburicu.

8 Koperta - prekrivač za duple krevete. (Vlatković 2003)

19 Kuvarice - komad tekstila, najčešće četvrtastog oblika s natpisom, koji su ljudi vješali u kuhinji iznad peći. (Vlatković 2003)

20 Od njemačkog sticken, što znači vesti. (Klaić 1986:1310.).

21 Eleonora Prpić Lejina, Veljun.

22 Kiklja - haljina ili suknja od kupovanog materijala. (Vlatković 2003) Kiklje kao dio opreme mačkara naveo je Marko Pavelić Mijatin iz Žuljevića.

23 Bušt - džemperi bez rukava. (Vlatković 2003)

24 Luka Krmpotić Brnde, Veljun; Eleonora Prpić Lejina, Veljun.

25 Ivan Krmpotić Bokulić, Veljun; Eleonora Prpić Lejina, Veljun; Grgo Prpić Miškec, Gorica.

26 Ante Krmpotić Škobac, Škopci. 
U povorci je važnu ulogu imao i vođa koji je bio maskiran jednako kao i drugi sudionici ophoda. Jedino je u Šojatskom Dolcu za vođu zabilježen naziv Mesopust, a birali su ga sudionici povorke između sebe. Mesopusta je pretežito predstavljao jači muškarac; važan je kriterij pri odabiru bila i elokventnost te vesela narav pojedinca. ${ }^{27}$ Oblačio se u žensku odjeću crne boje, a na glavi je imao crnu maramu. Karakterizirali su ga brkove: ako nije imao vlastite, oblikovao bi ih od ovčje kože i vune. Mesopusta se moglo razaznati i po podrugljivom, isplaženom jeziku: crvenoj krpici, širokoj dva centimetra, koja mu je visjela do prsa. Sa sobom je nosio metlu, a pred domaćinima je glas mijenjao tako da nalikuje ženskom. U Mrzlom Dolu vođa povorke bio je odjeven u dugačke hlače i poširok, naopako navučen kaput. Na glavi je imao šešir i naočale, a lice je prekrivao papirom. ${ }^{28} \mathrm{U}$ većini slučajeva vođa povorke bio je muškarac; jedino je u Veljunu zabilježeno da je tu funkciju mogla vršiti i žena, ukoliko dobro poznaje područje koje povorka namjerava obići. ${ }^{29}$

Uz krivoputske mačkare, jednako važnu sastavnicu pokladne interakcije činili su domaćini čija su kućanstva ophodnici obilazili. Njihova uloga pri ovom teatrabilnoj običajnoj praksi nije bila nimalo način onoj pasivnoj poziciji "publike" pri klasičnim predstavama institucionalnoga kazališta. Maskirana povorka obilazila je sva sela na ovom području i pri tom svraćala u svaku kuću. Dolazak mačkara čuo se iz daleka jer su pravile veliku buku vikom, glazbom i pjevanjem. Kad je povorka došla pred kuću pjevali bi i plesali ${ }^{30}$, a domaćini su ih dočekivali, darivali fritama i sličnim jestvinama, priključivali im se u pjesmama, naručivali određene plesne izvedbe, vodili s njima šaljive dijaloge, poticali ih na lascivne postupke, u nekim slučajevima i sami nastojeći taktilno otkriti kojega je spola njihova Luca. Iskazivanje gostoprimstva mačkarama, kao i toleriranje njihovih nepodopština (razbacivanja pepela po kući, razmještanja namještaja, dobacivanja seksualnih aluzija članicama kućanstva, fingiranje koitusa i sl.) doprinosilo je položaju koji dotična obitelj zauzima unutar zajednice. Posebno dobrim domaćicama nastojale su se pokazati mlade nevjeste koje su brak sklopile nakon prošlogodišnjih poklada. ${ }^{31}$ Bogato gošćenje moglo se očekivati i u onim domovima u kojima je bilo djevojaka u dobi za udaju - na taj su način njezini ukućani davali do znanja potencijalnim proscima da je riječ o dobroj partiji. ${ }^{32} \mathrm{~S}$ druge strane, obitelji koje bi odbile mačkarama otvoriti vrata svojega doma postale bi žrtvom pokladnih nepodopština: ophodnici su ih simbolički kažnjavali pjevanjem podrugljivih pjesmica, poput: Što si, mala, zatvorila vrata, oli nemaš na krevetu plata, podizanjem buke, pravljenjem nereda u dvorištu, sakrivanjem imovine ili barikadiranjem ulaznih vrata izvana. ${ }^{33}$ Mačkare nisu obilazili jedino kuću u kojoj je netko te godine umro ili bio bolestan.

Ophode maskiranih skupina Krivim Putem omogućavali su i svi oni nemaskirani sudionici koji su mačkarama iz svoga sela pomagali u pripremama, izrađujući, prikupljajući ili uređujući njihovu odjeću, uređujući ih i opremajući za put, kao i u spravljanju završne gozbe. Koliko su pri izvedbi pokladnih događanja bili značajni i ti "zakulisni” pojedinci govori i činjenica da se nekih od njih njihovi suseljani sjećaju upravo po vremenu i trudu koje su ulagali pomažući mladima da se što primjerenije pripreme za svoj mačkarani pohod krajem: Bila je tu jedna žena koja ih je najbolje (mačkare, op. a.) znala oblačit. Svake godine, dok je mogla, ona nji mačkarala, sve, njima je spremala, navlačila robu... nje više nema, ona je sve

27 Izraz Mesopust na području Krivoga Puta jedini je spominjao Ivan Krmpotić Šoparin iz Šojatskog Dolca, koji je samoinicijativno spomenuo ovaj naziv te potom detaljno opisao lik. Naziv "mesopust" u pravilu je korišten u drukčijem značenju: prema kazivanjima, on i danas označava ili dan prije Čiste srijede ili cijelo mesopusno razdoblje. Ipak, u budućim istraživanjima trebalo bi u krivoputskim selima dodatno provjeriti značenja ovog pojma.

28 Mile Prpić Popić, Mrzli Dol.

29 Mara Tomljanović, Veljun.

30 Kazivači na ovom području ne sjećaju se posebnih pjesama koje bi se pjevale u pokladnom razdoblju i za vrijeme ophoda.

31 Luka Krmpotić Brnde, Veljun.

32 Eleonora Prpić Lejina, Veljun.

33 Ante Krmpotić Škobac, Veljun; Ivan Krmpotić Šoparin, Šojatski Dolac, zaselak Škopci; Luka Krmpotić Brnde, Veljun; Grgo Prpić Miškec, Gorica. 
mačkare pripremala, da budu lipe mačkare, da ne budu ružne. Uvik je znala najbolje kako namazat po licus ugljenom, ugljen ovaj od vatre uzmi i namaži. Bez nje nije bilo ništa. ${ }^{34}$ (usp. Vlatković 2005:333)

\section{SENJSKI ZIMSKI KARNEVALI ${ }^{35}$}

$\Gamma_{m}^{n}$ der so genannten Faßnacht treiben sie allerlen Mummern und Affenspiel so nur immer zu erdencken sehn mögen. Am Aschermittwoch legen sie ebenfalls ungewöhnliche seltsame Kleider an und bestreichen das Angesicht ganz Schwarz mit Guß von Pfannen Kesseln und laufen also alenthalben auf die Gassen vor ibre Häuser heraus ziehen daselbsten die Glocken und begehren daß man ihnen Meel Baumoel Brot und Wein bringen solle. Wann danndieser vermummten Leute sich eine genugsame Anzahl gesamelt hat machen sie auf dem Platz oder öffentlicher Strassen ein Feuer kneten aus Wasser und Mehl einen Kuchen rösten und braten setzen sich dann fressen saufen und treibenüberaus lächerliche Händl und betrauern absonderlich dabey deß Bacchi Tod. (Valvasor 1689:88) (U takozvanoj posnoj noći izvode svakojake maškarade i igraju se kao šimije kako se samo zamisliti može. I na Pepelnicu obuku neobično čudne haljine i čadom s pinjata i kotlova izmažu obraze da je sasvim crn, pa trče posvuda ulicama ispred kuća, potežu zvona i traže da im donesu brašna, ulja, kruha i vina. Kad se skupi dovoljan broj tih namaškaranih ljudi, načine na placi ili otvorenim ulicama oganj, od vode i brašna zamijese tijesto, prže ga i peku, pa tada posjedaju, jedu i piju i izvode neobično smiješne stvari, a pri tom osobito oplakuju Bakhovu smrt.) (Valvasor 1970:87) ${ }^{36}$ Tim je riječima Johann Weichard Valvasor u svojoj knjizi Die Ehre des Hertzogthums Crain prikazao senjske pokladne običaje, u kojima je imao prilike i sam sudjelovati više godina uzastopce, koncem pedesetih i početkom šezdesetih godina 17. stoljeća, kada je kao austrijski časnik boravio u tome gradu. Prema autorovu tumačenju, karnevalsku je povorku sačinjavala gradska mladež, s time da Valvasor ne određuje njihovu rodnu pripadnost pa ne možemo zaključiti jesu li se ophodu imale pravo priključiti i djevojke. Uz ove aktivnosti odraslih, Valvasor izdvaja i specifičan dječji angažman u pokladnom razdoblju i neposredno nakon njega, uprizorenja "ratova" između različitih gradskih četvrti. Autorov opis senjskih poklada usmjeren je u prvom redu na prerušene pojedince pa ne saznajemo mnogo o komunikaciji maskiranih skupina s njihovim nemaskiranim sugrađanima. Ipak, Valvasor spominje darivanje brašnom i drugim namirnicama, iz čega se može iščitati da ophodom nije bila obuhvaćena samo javna sfera, već su se postupci i želje maškara odnosile i na pojedinačna kućanstva, na što su im domaćini uzvraćali nagradom.

Više o interakciji prerušenih ophodnika i svih onih nemaskiranih sudionika koji su na različite načine doprinosili održavanju senjskih pokladnih zbivanja doznajemo iz kasnijih etnografskih zapisa. Senjske predstavljačke oblike koji su se ostvarivali dijalogom između ovih dviju strana opisivao je, primjerice, folklorist i književnik Nikola Bonifačić Rožin. Taj istraživač prikazuje odnose domaćina i njihovih prerušenih gostiju, pri čemu naznačava da se mačkare, za razliku od krivoputskih skupina, koje su znale i batinama kazniti preznatiželjne promatrače, nisu trudile posve prikriti svoj identitet, budući da su se upućivale susjedima i prijateljima koji su ih poznavali i očekivali: Poznate mačkare bi dolazile u večer u kuću, pa bi ih domaćini ponudili sa fritami i vinom (Bonifačić-Rožin 1954:29). Uz to, prikaz Bonifačića Rožina donosi drukčiju perspektivu u odnosu na uvriježeni istraživački fokus na same prerušene ophodnike, pri čemu se nerijetko zanemaruje širi kontekst unutar kojih se ophod ostvaruje kao i odjeci pokladnih zbivanja na svakodnevicu zajednice. Prolaz maskirane povorke gradskim ulicama, naime, ovaj autor opisuje iz perspektive kritički raspoloženih nemaskiranih promatrača: Na utorak, zadnji dan Mesopusta su delali maškare, a stariji su govorili 'mačkare'. Su obučeni u razna odijela, muško u žensko, a žensko u muško. I onda su se rugali ljudi ki gledaju sa strane, kad bi ka mačkara došla ružno obučena na korzo: - Gle ovu mačkaru: Kiklja gori, kiklja doli, kiklja ne će da govori. (Bonifačić-Rožin 1954:28)

34 Mile Popić, Mrzli Dol, zaselak Popići.

35 Sastavnice senjskoga zimskog karnevala podrobno su prikazivane u više radova u Senjskoj smišnoj kronici: godišnjaku za senjske-bunjevačke mesopusne običaje, šalu i zabavu, u izdanju Senjskoga muzejskog društva: usp. Bašić 1972:75; Glavičić 1972:72-74.

36 Preveo Z. Sušić. 
Za razliku od etnografskih prikaza krivoputskih mačkara, koji su pretežito depersonalizirani i anonimni, zamijenjeni općeprimjenjivom formulom $»$ naroda ${ }^{37}$ pri opisima senjskih zimskih pokladnih događanja češće se u prvi plan stavlja uloga pojedinih društveno angažiranih pojedinaca i gradskih udruga. Tako se, primjerice, u pokladnom tisku s konca 19. stoljeća invencija »Corsa« (šetnje građana prerušenih uglavnom u pseudopovijesne kostime središnjim trgom), odnosno njegov prijenos iz obližnjih karnevalskih središta Rijeke i Trsta u Senj, pripisuje skupini utjecajne i imućne mlade gospode. U članku se također naznačuju načini uključivanja pripadnika iz svih slojeva u tu vrstu pokladne zabave (primjerice, nabacivanjem konfetima i slasticama), a ističe se i uloga općinstva u poticanju i promicanju novih kulturnih praksi, koja se tumači kao presudna za njihovo daljnje održavanje: Na pokladni utorak iznenadila nas je ugodna novost 'Corso' u posljednji čas prije podneva dogovorila se nekolicina, da prirede improvizirani korso (sic!), koji je u istinu uspio. U 4 sata po podne dovezlo se 9 kočija na obalu gdje se po običaju sabrala nepregledna množina svijeta iz svih slojeva. U povorci sudjelovahu obitelji ovdašnjih veletrgovaca Olivierija i Paškića, činovnika tvornice duhana $i$ više druge mlade gospode i nekoliko gosti iz Brinja. Nabacivanje sa confetima, raznolikim bombonima, smokvama i naranžama bilo je vrlo živahno, tako da pod konac upravo žestoko, a poznavaocu tršćanske riječi i zagrebačkog 'Corsa' tvrde, da i senjski živahnošću i vatrom u svom malenom opsegu nije zaostao. Obćinstvo je novu zamisao corsa sa simpatijom pribvatilo, tako da bi se na godinu uz pripreme moglo postati Corso za čitavo Primorje i Krajinu. (Uredništvo Narodnih novina 1972:76)

Pokladni kontekst u kojem se izrazito zrcalila svakidašnja društvena gradska stratifikacija jesu balovi pod maskama. Postojala je, naime, podjela na tzv. nobelbale, plesne večeri namijenjene isključivo senjskim uglednicima pa su se na njima pojavljivale samo ne familije ke bidu bile pozvane, te na pudlbale ili publiće, o kojima su se obavijesti postavljale po čitavom gradu pa je na njih mogal svaki doći. (Bašić 1972:75) Organizacija pokladnih balova predstavljala je jednu od zadaća istaknutijih gradskih društava. Tako su godine 1893. održana tri takva plesa, od kojih su za prvi bila zaslužna senjska obrtnička udruženja, drugi je održalo gimnastičko društvo "Sokol«, i to s dobrotvornom namjenom, budući da su tom prigodom prikupljana sredstva za izgradnju nove bolnice; konačno, zaključni je ples održan na pokladni ponedjeljak priredio odbor mlade gospode imenom "Zvonimirci«, a okupio je članove nižega i srednjega staleža. (Bašić 1972:75) Slične su balove na prijelazu iz 19. u 20. stoljeće priređivali i Glazbeno društvo, Zadruga »Uskok«, udruženje gimnazijalaca i sl. (Schneider 2001:7)

Uz to, u popularnim prikazima senjskoga zimskog karnevala u prvi se plan nerijetko stavlja uloga pojedinaca - nositelja senjske karnevalesknosti. Tako se, primjerice, u mesopusnoj kronici donose crtice iz života Nacia, glasovitog gradskog šaljivdžije bez čijeg je angažmana senjski karneval u razdoblju između dva svjetska rata bio nezamisliv: Bil van je pravi Senjanin iz fine familije. (...) Znalo ga je iz Senja nestat po leto i više dan. (...) Vajik je to bila senzacija kad bi se Nacio vratil iz svita. Sićan se da su mu znali govorit: "Ala, skini kapu ako si kapac!" Jer ako je bil ošišan, znalo se da je nafriško pušćen iz rešta. (... ) Znal je "zakuvat" $i$ ništo većega, al to je bilo naretko. Nacio i danas živi u sjećanju starijih Senjanov, a da bi i mladi svit saznal ništo o njemu evo nikuliko angdot (sic!) iz njegovog života. (Uredništvo Smišne senjske kronike 1972:52)

\section{KOME JE NAMIJENJEN SENJSKI LJETNI KARNEVAL? ${ }^{38}$}

$\mathrm{L}$ jetni karneval u Senju smatra se nastavkom Venecijanskih noći koje su od 1948. do 1965. godine bile dio turističke ponude Senja. Dvije godine kasnije organiziran je prvi ljetni karneval koji je u početku trajao svega dva dana, da bi se postupno ljetna pokladna ludovanja produžila na četiri do najviše osam dana. Na prvim ljetnim karnevalima sudionici su u najvećoj mjeri bili sami Senjani i gosti iz Novog Vinodolskog. Postupno su se u karneval počeli uključivati i turisti, prvo kao publika, a zatim spontano i kao

$37 \quad$ Usp. Pavelić 1973:183-184.

38 Nastankom i kronologijom Senjskoga ljetnog karnevala, kao i glavnim obilježjima ove manifestacije sustavno se bavila Sanja Schneider: usp. Schneider, 2001; ibid. 2002:75-103. 
sudionici povorke, da bi od osamdesetih godina započelo organizirano sudjelovanje gostujućih skupina iz Hrvatske i inozemstva. Maskirani sudionici čine povorku koja se kreće već utvrđenim putem od Velike place (Cilnice), kroz Velika vrata, ulicom Stjepana Radića, Starom cestom, Obalom kralja Zvonimira, Pavlinskim trgom, te ulicom Potok do Velike place. Povorka je posljednjih godina sastavljena prema ustaljenom redoslijedu. Na čelu povorke su djevojke s karnevalskom zastavom, zatim Gradska glazba i mažoretkinje, te Meštar karnevala s gostima. Slijede strane grupe, zatim grupe iz Hrvatske i na kraju povorke grupe iz Senja (Schneider 2001:22, 23).

Različitost i šarolikost skupina koje su ovim zbivanjima obuhvaćene naznačena je i u tekstu kojim je popraćena tematska izložba "Karnevalski običaji u Senju”, postavljena prigodom Međunarodnog dana muzeja u Gradskom muzeju Senj 2004. godine: Senj je poznat i po ljetnom karnevalu... Brojeći dosadašnje ljetne karnevale Grad će ove godine (2004., op. a.) organizirati 33. po redu Senjski ljetni karneval. Prošle godine na Senjskom ljetnom karnevalu sudjelovalo je preko 40-ak maškaranih skupina sa 1500 sudionika iz Senja, raznih hrvatskih gradova $i$ inozemstva. Ljetni karneval postaje glavna turistička atrakcija i doprinosi stvaranju dobrih medukulturnih odnosa unutar raznih karnevalskih skupina, posebno od 1996. godine kada je Senj kao karnevalski grad ušao u Udrugu europskih karnevalskih gradova - FECC, a karneval postao i službeno medunarodni. Ljetni karneval traje nekoliko dana. To je vrijeme plesa, zabave i ludovanja na najljepšsem senjskom trgu Cilnici, uz bogatu ugostiteljsku ponudu, dobru glazbu i pjesme pjevača i glazbenih sastava. Sastavni dio Senjskoga ljetnog karnevala je karnevalska kostimirana povorka koja je svake godine sve bogatija kostimiranim grupama i brojem sudionika. To je uvijek duhovita i vesela povorka bez dobnog ograničenja, koju pozdravljaju i dive joj se mnogobrojni okupljeni gradani i turisti, od kojih se neki, poneseni glazbom i plesom, aktivno uključuju u karnevalske ludorije. (Ljubović 2004)

Brojne dihotomije kroz koje možemo opisati ovaj festival svjedoče o njegovoj mnogostrukosti i raznolikosti. Među organizatorima se opaža čitav niz uključenih aktera, od individualne do globalne razine: od pojedinaca preko lokalnih društava i ustanova do nacionalnih, pa i međunarodnih organizacija. Često se u prvi plan stavlja uloga gradskih društava i kulturnih ustanova (kao što su Dom kulture Senj, Gradski muzej Senj, Gradska glazba, udruga ugostitelja itd.), zatim senjskoga poglavarstva te posebice Turističke zajednice grada Senja, pri kojoj je i začeta ideja da se komadić tradicije iskoristi u turističke svrhe. (Schneider 2001:9) Predstavnici svih ovih senjskih udruga i organizacija čine Karnevalski odbor, zadužen za osmišljavanje i koordinaciju programa događanja te simboličko preuzimanje ključeva grada tijekom manifestacije. Od 1996. godine, od ulaska Senja u mrežu europskih karnevalskih gradova, možemo pratiti i upliv međunarodne krovne organizacije FECC-a (Foundation of European Carnival Cities) na strukturu senjske manifestacije. Pritom se može uočiti preuzimanje pojedinih postupaka, predstavljačkih oblika, tehnika prerušavanja i rekvizita koji predstavljaju zaštitni znak te europske karnevalske udruge pa se time prenose i u sve gradove koji postaju njezinim članovima, o čemu svjedoči sljedeći podatak: Karnevalski dužnosnici su odjenuli već tradicionalne odore čiji sastavni dio čine plavobijele kape u obliku pijetlove krijeste s oznakom FECC-a. Prema riječima V. Petera, u Nizozemskoj je bio običaj da se na karnevalu žrtvuje pijetao. S obzirom da FECC ima svoje sjedište u Amsterdamu, ne čudi što je ta kapa postala simbolom Udruge. Svi dužnosnici gradova-članica Udruge odijevaju tu specifičnu 'uniformu' u svim karnevalskim svečanostima. (Schneider 2002:83) No istodobno se ističe doprinos istaknutih pojedinaca, poduzetnika, kulturnih djelatnika i umjetnika, poput senjskog humorista Vladimira Zudeniga Ćuka, koji već godinama prigodom Senjskoga ljetnog karnevala objavljuje svoje Stidne novine, s time da mu kao medij na kojem predstavlja svoje pjesme i karikature služi pročelje vlastite kuće na Velikoj placi. (Schneider 2001:37)

Brojni oblici komunikacije mogu se uočiti i ako se usmjerimo na izvođače, kako na organizirane maskirane skupine, tako i na individualne predstavljače. Međunarodni karakter suvremenog Senjskog ljetnog karnevala odražava se u nastupima brojnih gostujućih skupina iz inozemstva: tako su, primjerice, 2000. godine u povorci senjskim ulicama sudjelovali predstavnici Fane u Italiji, Köszega u Mađarskoj, Wieluna u Poljskoj, Vratimova i Rimova u Češkoj te Seneca u Slovačkoj. (Schneider 2002:84) Uz to, za fiktivnim karnevalesknim identitetom tih dana posežu i brojni individualni turisti koji svoj godišnji odmor provode 
u Hrvatskom primorju. Zamisao je Turističke zajednice grada Senja da se posjetiteljima s dugogodišnjim prerušavačkim "stažom" u Senju dodijele posebne nagrade. Usporedo s time, Senj se posljednjih godina iskristalizirao kao utjecajno karnevalsko središte u nacionalnim okvirima. Senjska ljetna scena tako okuplja brojne maskirane skupine iz različitih hrvatskih krajeva, od kojih su najzastupljenije one iz Hrvatskog primorja i Gorskog kotara. No, na tom su festivalu svoj program izveli i mnogi karnevalski likovi koji predstavljaju zaštitni znak pojedinih hrvatskih regija ili gradova, kao što su kastavski zvončari, mućki didi, međimurski naphanci, slavonski bušari, a svojom se satirom sa senjske pozornice oglasila i samoborska Sraka. O Karnevalu kao prigodi za komunikaciju Senjana s drugim hrvatskim gradovima snažne pokladne tradicije govori komentar koji su svojim domaćinima uputili predstavnici maskirane skupine iz Jastrebarskog: 10 godina nije mala stvar, a upravo toliko mi iz Jaske dolazimo na karneval. Budući da je to ipak 10 godina s pravom se možemo nazvati dijelom Senjskog ljetnog karnevala. Tokom godina mnogo nas je dolazilo, ali okosnica naše ekipe još i danas je tu. Čak nam se pridrǔ̌io prijatelj iz Berlina (SALE) koji već četvrtu godinu dolazi samo na karneval. Iznimna nam je čast što nas ljudi u Senju prihvaćaju ovako vesele i pomalo 'neozbiljne'. Evo nas $i$ ove godine te se iskreno nadamo da ćemo doći i dogodine. VELIKI POZDRAV SVIM SENJKINJAMA i SENJANIMA - "MISSICE IZ JASKE" 39

Unatoč sve eksponiranijem nacionalno i globalno prepoznatljivom licu Senjskoga ljetnog karnevala, unatoč činjenici da sami Senjani festival definiraju kao kulturni proizvod namijenjen u prvom redu senjskim posjetiteljima, posredstvom kojeg taj grad zaživljava kao specifična turistička destinacija, ovo događanje svejedno igra presudnu ulogu pri samopercepciji građana Senja, pri konstruiranju njihova razlikovnog lokalnog identiteta. Naime, u povorci i dalje brojčano, ali i elaboriranošću svojih predstavljačkih oblika te karnevalesknošću svojih maski prevladavaju sami Senjani: svaka gradska četvrt te zaposlenici brojnih lokalnih poduzeća formiraju zasebne maskirane skupine, pripremajući za tu priliku i po dvadesetak alegorijskih vozila od njih ukupno četrdesetak koliko ih se u ovom desetljeću obično pojavljuje na Karnevalu. U povorci se mogu vidjeti maske s temom različitih životinja (muha, leptira, paunova), putovanja kako u prošlost (Druidi, Rimljani) tako i u daleke krajeve svijeta (Havajci, Arapi, Divlji zapad, Kinezi), a česta je i inverzija spolova pa se muški sudionici maskiraju u missice, balerine ili mažoretkinje. (Schneider 2001:25, 27) Ponekad je njihova tema inspirirana upravo gradskim kulturnim naslijeđem: tako su 1971. godine ljetnu karnevalsku povorku predvodila grupica muškaraca preodjevenih u senjske uskoke. (Meštar karnevala Đeno 1972:58) Nadalje, parodijska je oštrica karnevalskih predstavljačkih oblika vrlo često usmjerena prema manjkavostima, propustima i ljudskim slabostima članova lokalne zajednice te prema problemima s kojima se Senjani susreću u svojoj svakodnevici. Govor se karnevalskog meštra, unatoč činjenici da velik dio publike ne čine Senjani te unatoč kritikama kako se sadržaj meštrova obraćanja često poziva na one mjesne sitnice koje život znače pa time nije razumljiv širem krugu slušatelja, ${ }^{40}$ i dalje izriče na narječju domaćem: Čuli smo da se gimnazija i pučka škola proširevadu, al' ne za njihove potribe, nego će se uz njih nažuntat i stanbena kuća za penzionere. Pametno rješenje. A dica neka i dalje gredu vježbat pol ure dalje od kuće i ondat se nako potni vraćadu nazad. (...) Nemojte se čudit ča je "Automobilia" zaprta. Puno su delali priko zime, pa su uzeli kolektivni dopust. A dok se oni iznovetka skupidu, dotle će van, tako da znate, popravljat avte Masa, Drasa ili Markina. (Meštar karnevala Đeno 1972:57)

Senjani, dakle, svojim izvedbama na Senjskom ljetnom karnevalu odašilju poruku o jedinstvenosti senjskog humora i o značaju karnevalesknoga smijeha za održanje gradskoga duha: Senjani su tog 1967. leta pokazali Evropi i našoj okolici... da još ni nestal senjski duh, da živi humor, smih, veselje i lipa tradicija maškaranja i bali. ${ }^{41}$ (Schneider 2002:78) No, ponekad se začuju i drukčija tumačenja toga kome je sve Senjski ljetni karneval namijenjen: Senj je u principu pravi bunjevački grad... Oni (Senjani, op. a.) su uvi-

39 www.tz-senj.hr/asp/Karneval_2006/Karneval_lista.asp, zadnje pregledano: 8. prosinca 2006.

40 Usp. Schneider 2001:36.

41 Dragan Vlahović Gago, meštar Senjskoga ljetnog karnevala, Senj. 
jek govorili „doklaćenci“, ali Senj je pravi bunjevački grad. Medutim, to su Senjani uvijek stavljali sa strane. (...) Prije nešto godina su se Bunjevci baš uključili u taj Senjski... karneval, ali se oni apsolutno nigdje nisu spominjali. Postoji jedan list, "Metla i škavacera"... i tu su obično bile dogodovštine, ali iz Senja i Bunjevci, to ovi s Krivoga Puta, nikad se nisu spominjali. A bilo bi normalno da se i o Bunjevcima govori, i oni u tom Karnevalu sudjeluju. ${ }^{42}$

\section{KRIVOPUĆANIN NA SENJSKOM LJETNOM KARNEVALU}

C ilj je ovoga poglavlja pokušati progovoriti o Bunjevcima na Senjskom ljetnom karnevalu, o njihovoj ulozi u urbanom karnevalskom događanju i o značenjima koja ova manifestacija danas poprima za Krivopućane. Naime, više je stanovnika Senja podrijetlom s Krivoga Puta istaknulo da toga dana svakako nastoje ne napuštati grad te da se sve veći broj primorskih Bunjevaca uključuje u senjsku maskiranu povorku. ${ }^{43}$ Nerijetko se i stanovništvo još uvijek naseljeno na Krivom Putu tijekom karnevalskih događanja spušta u grad te se, prerušeni, priključuju povorci mačkara ili je barem prate iz publike. U tom se trenutku odnos bunjevačkih i senjskih pokladnih ophoda prestaje izražavati kroz niz suprotnosti, kojima se urbana sredina nastoji simbolički razgraničiti od svoje ruralne okolice; senjski karneval u ovom slučaju omogućuje i širu, regionalnu identifikaciju.

Uloga Krivopućana u Senjskom ljetnom karnevalu, iskustva i doživljaji svakoga od sudionika, individualnih posjetitelja, budući da stanovnici Krivoga Puta ne odlaze u Senj kao koherentna maskirana skupina, nesvedivi su na zajednički nazivnik. Stoga ću ovu temu pokušati rasvijetliti osvrtom na uključivanje Grge Prpića Miškeca iz Gorice u senjsku ljetnu povorku - ovaj je sedamdesetogodišnjak u više navrata predvodio mačkaranu skupinu sastavljenu od samih Senjana pri njihovu prolazu gradskim ulicama. Čest motiv senjskih naracija o nedavnim gradskim pokladnim zbivanjima predstavlja pojavljivanje Grge Prpića Miškeca na karnevalskoj sceni: Taj Miškec odozgo, on je uvijek glumio, on stalno, svaki bal ljetni. A on je ima dobroga konja i njega isto obuci uvijek... glumio je nekog vojskovođu, dojaha je na konju. ${ }^{44}$ Temeljne kriterije pri odabiru predvodnika gradske maskirane skupine u ovom slučaju ne predstavljaju višegeneracijska pripadnost senjskoj zajednici, pozivanje na uskočko naslijeđe, ukorijenjenost u urbanoj kulturi i sl. Razlozi takvoga odabira, kako se očituje na primjeru Grge Prpića, mogu biti posve jednostavni: bira se veseljak te vlasnik konja koji je dovoljno miran da bez otkazivanja posluha može podnijeti karnevalsku vrevu.

U Senju je povorka ta, to je bilo nešto posebno. Onda su jednoga uzeli, kao budi car...nedaleko tu živi, bio je tu kod mene u subotu, Miškec iz Gorice. On ima obično konja i onda se on pozove na tu povorku s tim konjom. (...) Njega zovu zato, on je isto malo otvoren onako čovjek... I on je stalno voda bio te povorke. Na konju je jašija, obučen u kao neku oficirsku robu, vojničku je kapu ima uvijek i on je sadržava tu kao neki komandant, komandir. I on je stim konjem naprvo išao, konj ide mirno naprijed, oni su otraga, tambure, oni bubnjevi... to cijeli grad zvoni. Moga si čuti uveče kad je bilo tiho, ovde smo mi čuli da bi se sviralo. (...) A poznat je on dole. ${ }^{45}$

Među gradskim mačkaranim skupinama u okviru Senjskoga ljetnog karnevala nerijetko se svojim maskiranjem i tematskim predstavljačkim oblicima ističe skupina koju je okupio Senjanin Mate Lopac. Skupina obuhvaća dvadesetak mačkara, a ima razgranatu mrežu nemaskiranih sudionika koji pomažu u pripremama, izradi kostima, opremanju alegorijskih kola, pripravljanju zakuske i sl. Redom je riječ o ljudima rođenim u Senju, uz jednog posebno pozivanog člana - Grgu Prpića Miškeca iz Gorice. Njegovim se sudjelovanjem osigurava smjehovnost nastupa, budući da je Miškec u cijelom Senju na glasu po svojoj sklonosti druženju i zbijanju šala. Stoga nerijetko preuzima ulogu nositelja karnevalesknosti te skupine.

42 Jadranka Tomljanović, Zagreb.

43 Eleonora Prpić Lejina, Veljun; Mirko Prpić Cungo, Senj.

44 Mirko Prpić Cungo, Senj.

${ }_{45}$ Ivan Krmpotić Šoparin, Šojatski Dolac, zaselak Škopci. 
Tako je po raspadu Jugoslavije, kada se njegova skupina parodijski obrušila na predstavnike Jugoslavenske narodne armije, pri karnevalskim zbivanjima on usvojio fiktivni identitet generala Rašete: Jednom sam u Rašetu, njega sam imitira, on je bija partizanski general, tako ima neku posebnu kapu njegovu, gonija sam narod, ja sam jaši i sve tjera prid sobom. Taj je nastup strašno puno pažnje privuka, kad sam doša prid binu, onda nas je stalno snimalo, svi su tili znat kako smo došli na tu ideju, kako se osjećam ko Rašeta.

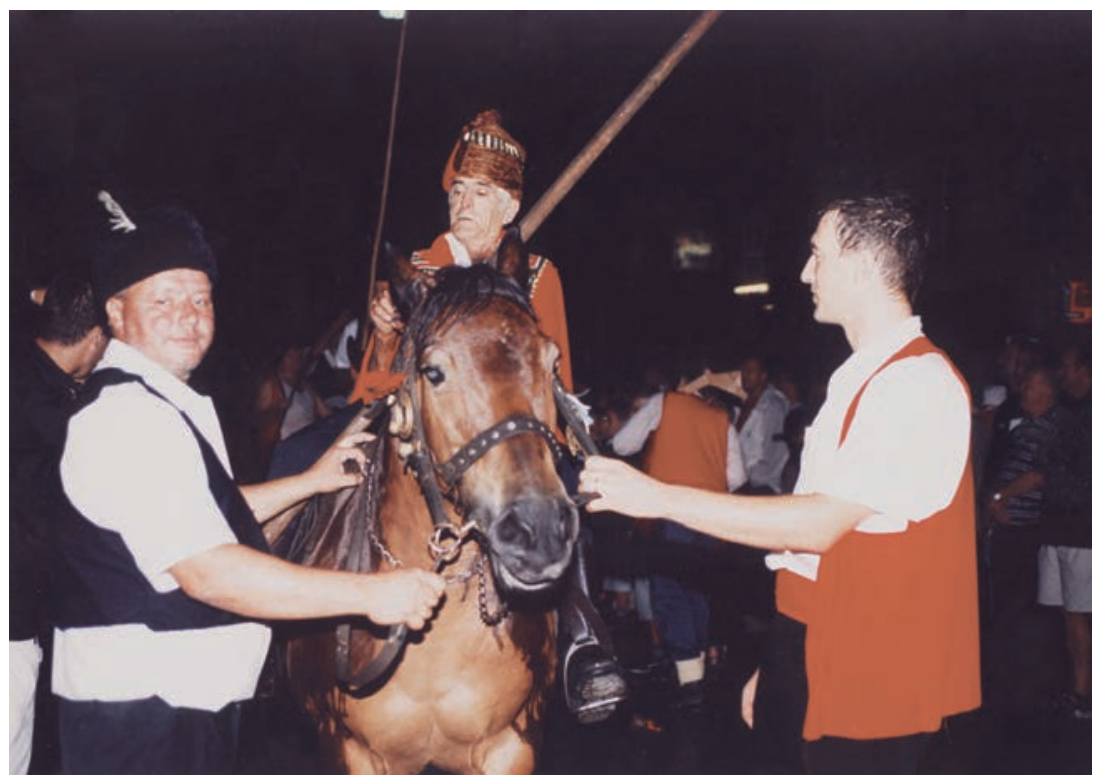

Slika 2: Grga Prpić Miškec prerušen u sinjskoga alkara pri nastupu na Senjskom ljetnom kalendaru 2002. godine; i₹ fotoalbuma Grge Prpića Miškeca iz Gorice.

Pri drugom je svom zapaženom pojavljivanju na senjskoj karnevalskoj sceni 2002. godine Miškec bio opremljen kao alkar: vješta je senjska šilica izradila rekonstrukcije kostima za "alkare" i njihove "pomoćnike", koji su bakljama pratili Miškeca - "vojvodu” (sl. 2). Alkarski je vojvoda na konju, dovezenom u Senj kamionom i posebno urešenom, privukao veliku pozornost turista (svi nas vuci, hoće se slikat s nama, govorili su da je to najbolja razglednica sa Senjskog karnevala), gradskih organizatora, predstavnika drugih gradova-članova FECC-a i medija.

A kako to da su na Senjski karneval zvali Bunjevca odavde? Pa to je sve bunjevačko, više je Krivopućana u Senju nego pravih Senjana. Stolačana i tako. A niko konja nema nego ja. Svi drugi danas voze traktore. I znaju da je did veseljak, za društvo, za pismu, onda je to odma ljepše. Svi za to znadu. Onda šta je bitno jesi Senjanin, jesi Bunjevac, šta si. Važno je da maska uspije, da nam šala uspije i da se dobro proveselimo.

\section{ZAKLJUČNA RAZMATRANJA}

$\mathrm{I}_{\mathrm{d} \text { sto }}^{\mathrm{st}}$ straživači i ljubitelji običaja, u prvom redu tragajući za njihovim tradicijskim obrascima, pri obilasku depopuliranih ruralnih hrvatskih područja (što su atributi kojima se svakako može okarakterizirati i Krivi Put) nerijetko konstatiraju da se običajni postupci u suvremenom kontekstu prakticiraju samo sporadično, da je došlo do "infantilizacije kulture”, pri čemu se ostaci nekadašnjih "ozbiljnih" obreda zadržavaju u "neozbiljnim” dječjim igrama; ukratko, da se običajna praksa dotičnog lokaliteta jednostavno "ugasila” te da jedino vrijedno bavljenja predstavljaju sjećanja preostalih stanovnika na nekadašnje, danas nepostojeće običaje.

No, razlog iz kojeg su senjska karnevalska zbivanja privukla našu pozornost nije njihova vizualna atraktivnost, glasnoća i medijska sveprisutnost, niti potreba da se nakon prebiranja po sjećanjima Krivopućana pozabavim nečim još živim, pulsirajućim i neponovljivim. Naime, senjski karnevali bili su stalno mjesto 
u naracijama stanovnika toga kraja i to ne samo kao referentna točka o tome kako bi "pravo" pokladno ludovanje trebalo izgledati (premda sam često nailazila i na tumačenja koja su nekadašnje krivoputske poklade kontrastirala sa senjskim karnevalima, čemu je pripisivan i vrijednosni sud koji ruralnoj običajnoj praksi pripisuje "inferiornu drugotnost”). Naši su nam sugovornici iz senjskog zaleđa o gradskim karnevalima pripovijedali kroz prizmu vlastita uključivanja u ta događanja, o svojem individualiziranom karnevalu koji je, eto, ostvaren u Senju.

Pokladni običaji stanovnika Krivoga Puta ni u jednom trenutku svojega dosadašnjeg postojanja nisu pokazivali prepoznatljivost svojstvenu nekim drugim hrvatskim lokalitetima, pa i samom Senju, niti su uključivali kontinuitet etnografskog praćenja. Ni u jednoj terenskoj bilješci ne opisuju se distinktivne, ručno rađene primorsko-bunjevačke maske, specifični postupci i pučka tumačenja kakva se rijetko potvrđuju u drugim krajevima. I još k tome, danas se na Krivom Putu u pokladno vrijeme ne događa gotovo ništa! Svejedno, smatram da je pokladna praksa, ona koja se odvijala u tim selima do sedamdesetih godina 20. stoljeća, ali i ona današnja, vrijedna etnološkog zanimanja. Možda upravo stoga što se u svojoj suvremenoj pojavnosti najintenzivnije ostvaruje negdje drugdje, u Senju. Sudjelovanje stanovnika s Krivoga Puta u senjskim karnevalima možemo pratiti (barem) iz dvije perspektive. Jedno polazište predstavlja kulturna praksa iseljenoga bunjevačkog stanovništva trajno nastanjenog u tom gradu. Za njih senjski karneval postaje obilježjem njihove nove lokalne identifikacije i interakcije sa sredinom čiji su danas dio. Drugo su Krivopućani koji se redovito na karnevalske dane iz svojih rodnih sela spuštaju u grad. Time oni senjske karnevale, zimske i ljetne, transformiraju u zgode koje zauzimaju istaknuto mjesto u primorskobunjevačkom godišnjem kalendaru, u događanja u kojima bi bilo grijeh ne sudjelovati ${ }^{46}$ u običaje koje krivoputska zajednica počinje poimati kao podjednako svoje.

\section{LITERATURA I IZVORI:}

BAŠIĆ, Frane (1972): Mesopusne uspomene starog Senjanina ili “Mesopust biži, ki ča dobije nek’ drži”, Smišna senjska kronika: Godišnjak za senjske-bunjevačke mesopusne običaje, šalu i zabavu, 1:75, Senj.

BONIFAČIĆ ROŽIN, Nikola (1954): Folklorna grada iz Senja i sjeverne Dalmacije, rukopis Instituta za etnologiju i folkloristiku br. 274

BRATANIĆ, Branimir (1959): Etnološki atlas Jugoslavije, Etnološki pregled, 1:9-18, Zagreb.

DRŽIĆ, Marin (1987): Djela. Ur. Frano Čale, Biblioteka Prolog, Velika edicija, Zagreb.

GLAVIČIĆ, Ante (1972): Predgovor, Smišna senjska kronika: Godišnjak za senjske-bunjevačke mesopusne običaje, šalu i zabavu, 1:3-4, Senj.

GLAVIČIĆ, Ante (1972): Mesopusni običaji u Senju i okolici, Smišna senjska kronika: Godišnjak za senjske-bunjevačke mesopusne običaje, šalu i zabavu, 1:72-74, Senj.

GLAVIČIĆ, Ante (1996): Spomen-ploče i obilježja u Senju i okolici, Senjski zbornik, 23:341-376, Senj.

LOZICA, Ivan (1997): Hrvatski karnevali. Golden marketing, Zagreb.

LJUBOVIĆ, Blaženka (2004): Karnevalski običaji u Senju, katalog izložbe, Gradski muzej Senj, Senj.

Meštar karnevala ĐENO, Kronika V. letnog karnevala, Smišna senjska kronika: Godišnjak za senjske-bunjevačke mesopusne običaje, šalu i zabavu, 1, Senj, 1972, 56-60.

Uredništvo NARODNIH NOVINA 1893, Pokladna bilanca - senjski Korso, Smišna senjska kronika: Godišnjak za senjske-bunjevačke mesopusne običaje, šalu i zabavu, 1, Senj, 1972, 76.

PAVELIĆ, Rikard (1973): Bunjevci. Osobna naklada, Zagreb.

SCHNEIDER, Sanja (2001): Senjski ljetni karneval, diplomski rad, Odsjek za etnologiju i kulturnu antropologiju Filozofskog fakulteta Sveučilišta u Zagrebu, Zagreb.

SCHNEIDER, Sanja (2002): Senjski Ljetni karneval, Etnološka tribina, 25:75-103, Zagreb.

46 Grgo Prpić Miškec, Gorica. 
SENJANIN IZ SVITA, Zelje kuma Mile i prašćevina kume Marije, Smišna senjska kronika: Godišnjak za senjske-bunjevačke mesopusne običaje, šalu i zabavu, 1, Senj, 1972, 55.

Uredništvo SENJSKE METLE, Razgovor parone Karle i Luce!, Smišna senjska kronika: Godišnjak za senjske-bunjevačke mesopusne običaje, šalu i zabavu, 1, Senj, 1972, 25-28.

SENJSKA LOŽA IZ ZAGREBA, Senjani iz svita - onima u Senj, Smišna senjska kronika: Godišnjak za senjske-bunjevačke mesopusne običaje, šalu i zabavu, 1, Senj, 1972, 14. Uredništvo SMIŠNE SENJSKE KRONIKE, Nacio, Smišna senjska kronika: Godišnjak za senjske-bunjevačke mesopusne običaje, šalu i zabavu, 1, Senj, 1972, 52.

ŠKRBIĆ ALEMPIJEVIĆ, Nevena (2003): Prilozi poznavanju primorsko-bunjevačkog identiteta, Senjski zbornik, 30:425-444, Senj.

ŠKRBIĆ ALEMPIJEVIĆ, Nevena (2006): Krivoputske poklade i senjski karnevali: Uključivanje Krivopućana u ophode s maskama, Senjski zbornik, 33:377-404, Senj.

Upitnice Etnološkog atlasa (UEA), svezak IV, tema br. 137. Ophodi s maskama, pokladni običaji, ljuljanje, Arhiv Odsjeka za etnologiju i kulturnu antropologiju, Filozofski fakultet u Zagrebu.

Zagreb, 1960. Fd 241, lokalitet: Krivi Put.

VALVASOR, Ivan Weikhard (1970): O Senju i Senjanima, (s njemačkog preveo Zvonimir Sušić), Dometi, 8:78-93, Rijeka.

VALVASOR, Johann Weichard (1689): Die Ehre des Hertzogthums Crain, druga knjig., Laybach-Nürnberg \& Dr. Rudolf Trofenik, München.

VLATKOVIĆ, Aleksandra (2005): Godišnji običaji primorskih Bunjevaca, Senjski zbornik, 32:317-348, Senj.

ZVRKO, Ratko (1963): Maškarama se sve oprašta: Luda snježna noć, Globus, 191:20-25, Zagreb. 